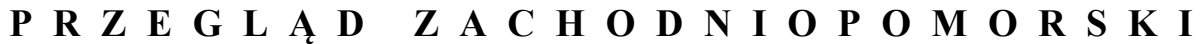 ROCZNIK XXXIII (LXII) ROK 2018 ZESZYT 3
}

\author{
Michal Pozorski \\ Uniwersytet Szczeciński, Wydział Humanistyczny \\ e-mail: michalpozorski@gmail.com
}

\section{Japoński wywiad I Jego beędy podczas woJny Na Pacyfiku. JAKICH BEĘDÓW NALEŻY UNIKAĆ?}

Słowa kluczowe: wywiad, II wojna światowa, cesarska Japonia, wojna na Pacyfiku, działania szpiegowskie, Hongkong

Keywords: intelligence service, the Second World War, the Imperial Japan, the Pacific War, spy activities, Hong Kong

II wojna światowa ukazała, jak wielki wpływ na prowadzanie działań ma informacja. Nie będzie przesadą stwierdzenie, że w wielu wypadkach to zdobyta informacja decydowała o dalszych kierunkach ataków czy nawet planowaniu całych kampanii lub operacji. Umiejętność odczytania, przechwytywania i łamania szyfrów wrogich wiadomości stała się nieodzowną częścią konfliktu, podobnie jak skuteczne ukrywanie własnych planów czy wiadomości. By sprawnie wykorzystać zdobyte informacje, potrzebne są umiejętności ich opracowania, skutkiem czego konieczne stało się kształcenie wyspecjalizowanych jednostek zdolnych do wykorzystywania swojej wiedzy i działania na tym polu ${ }^{1}$. Na wstępie należy poruszyć temat pozyskiwania źródeł informacji. W roku 1979 Brytyjczycy opublikowali kompilację instrukcji pt. British Intelligence the Second World War ${ }^{2}$. Zbiór ten został uznany za oficjalną część historii wywiadu i kontrwywiadu. Zawarto

\footnotetext{
${ }^{1}$ K. Kotani, Japanese Intelligence in World War II, Oxford 2009, s. 25-40.

${ }^{2}$ F.H. Hinsley, British Intelligence in the Second World War, London 1971.
} 
w nim informacje na temat państw Osi i działań wobec nich na terenie Europy, pominięto jednak działania w Azji czy na Bliskim Wschodzie. W opracowaniu znaleźć można informacje o tym, że mimo swojej rangi front azjatycki został oddany Amerykanom. Powodem tego była (i nadal jest) chęć utrzymania w całkowitej tajemnicy sposobów zdobywania informacji, metod łamania szyfrów czy wydarzeń dotyczących Pearl Harbor'; chciano także uniknąć dyplomatycznego konfliktu z Japonią. W związku z tym Brytyjczycy zadecydowali, że raport nie będzie zawierał kwestii związanych z działalnością wywiadowczą na terenach japońskich. Analogiczna decyzja o utrzymaniu tych danych jako tajnych zapadła również w USA. Jednym ze znaczących opracowań omawiających złamanie japońskich szyfrów była książka Dawida Kahna Łamacze kodów z 1968 roku. Autor ukazał sposoby i metody wykorzystane podczas „rozgryzania” szyfrów japońskich. Sam temat siły wywiadu oraz kontrwywiadu zarówno aliantów, jak i Japonii był już poruszany przez badaczy. Niestety refleksje płynące z tych prac są bardzo płytkie i powierzchowne. Badacze w większości zakładali, że japońskie szyfrogramy były słabo skonstruowane, a infiltracja Japonii nie nastręczała żadnych trudności, w związku z czym alianci nie mieli żadnych problemów w zdobywaniu potrzebnych danych. Amerykańskie zarzuty dotyczące początkowej łatwości w łamaniu kodów Japończycy kwitowali zwykłym szczęściem.

Większość instrukcji dotyczących kwestii wywiadowczych została zniszczona pod sam koniec wojny. Jedną z ocalałych był Podręcznik dla wywiadu, wykorzystywany przez armię japońską operującą w północnej części Chin. Składał się z instrukcji dotyczących pozyskiwania źródeł informacji czy zdobywania ich podczas trwania operacji wojennych. Poza tym omawiał takie kwestie, jak przekupstwa oraz szantaże, zdobywanie kontaktów czy choćby wykonywanie odpowiednich zdjęć. Następnym poruszanym w książce tematem były zagadnienia związane z radiokomunikacją. Poza tym znajdowały się w niej informacje na temat przechwytywania sygnałów o ruchach przeciwnika, monitorowania wrogich agencji czy wykorzystania szpiegów na polu bitwy. Oprócz podręczników tego typu, w których autorzy brali pod uwagę specyfikę danego teatru działań, istniały jeszcze tzw. listy wywiadu, znane jako skróty spraw lokalnych i zagranicznych. Aktualizowano je co miesiąc. Skupiały się na nowych informacjach pozyskanych przez wywiad. Były podzielone na rozdziały, w którym każdy był

3 C. Lutton, Pearl Harbor: Fifty Years of Controversy, „The Journal of Historical Review” 1991, vol. 11 (4), s. 431-477. 
przypisany do innego teatru działań. Każda informacja miała jasno określone pochodzenie, takie jak prasa, SIGINT $^{4}$, tajny telegram czy agencja. Wraz z końcem wojny amerykańskie MIS ${ }^{5}$ wydało komunikat, że Japonia do końca wojny nie była w stanie złamać wysokopoziomowych kodów Ameryki czy Wielkiej Brytanii ${ }^{6}$. Jednak po odkryciu kolejnych japońskich dokumentów oraz podjęciu tego tematu przez samych Japończyków deklaracja zaczęła być coraz mocniej podważana. Obie siły japońskie, czyli marynarka ${ }^{7}$ i armia lądowa ${ }^{8}$, były w stanie łamać amerykańskie czy brytyjskie kody dyplomatyczne. Ponadto Japończycy bez problemu radzili sobie również z kodami Sowietów czy Francuzów, nie wspominając o chińskich, które łamane były z ogromną łatwością. Mimo to tak zdobyte informacje nie zawsze miały realne zastosowanie, nawet ich „obrobienie" nie gwarantowało przydatności. Warto o tym pamiętać, gdyż w porównaniu z innymi źródłami wiadomości SIGINT były bardzo trudne do przetworzenia oraz wykorzystania. W tym wypadku warto przytoczyć słowa kapitana marynarki Yuzuru Sanematsu9: „SIGINT i jego przechwytywanie przez naszą sekcję wywiadowczą pokazały skuteczność naszych działań szczególnie w obszarze operacyjnym. Nie mamy żadnego żalu, że w wielu wypadkach takie informacje zostały przeszacowane. Skoro informacje SIGINT są jak świeże jedzenie, przez nieuwagę mogą się zepsuć i spowodować rozwolnienie. Dla amatora wywiadu rozróżnienie informacyjne jest trudne"10. Kolejnym ważnym źródłem informacji zostali różnego typu attaché czy doradcy. Informacje od nich zbierano nie

${ }^{4}$ SIGINT - signals intelligence - rodzaj działalności wywiadowczej/rozpoznawczej prowadzonej m.in. w telekomunikacji czy teleinformatyce. Inaczej zwany wywiadem (rozpoznaniem) elektromagnetycznym, elektronicznym. W najprostszy sposób wytłumaczyć można to jako działanie sprowadzające się do śledzenia aktywności nadajników i radarów przeciwnika, podczas którego odnotowuje się wszelkie prawidłowości, uwzględnia się przypadki szczególne i odstępstwa od reguł.

5 The Military Intelligence Service - jednostka wojskowa działająca w okresie II wojny światowej, składająca się z dwóch gałęzi, japońskiej oraz niemieckiej. Służyli w niej Amerykanie japońskiego pochodzenia.

${ }^{6}$ J. Bennett, W.A. Hobart, J.B. Spitzer, Intelligence and cryptanalytic activities of the Japanese during World War II, Walnut Creek 1986, s. 6.

${ }^{7}$ Cesarka Marynarka Wojenna Wielkiej Japonii (jap. 大日本帝国海軍) funkcjonowała od 1869 do 1947 r.; w skrócie IJN.

${ }^{8}$ Cesarska Armia Japońska (jap. 大日本帝国陸軍), japońskie siły lądowe funkcjonujące od 1867 do 1945r.; w skrócie IJA.

9 Y. Sanematsu, Joho Sakusen ni Tsuite (Zenhso), Tokio 1972, s. 58-61.

${ }^{10}$ K. Kotani, Japanese Intelligence in WW II: Successes and Failures, „NIDS Security Reports" 2009, No. 10, s. 6 . 
tylko we wrogich krajach, lecz także neutralnych. Warto wspomnieć o Szwecji, gdzie stacjonował generał Makoto Onodera ${ }^{11}$, czy Finlandii z pułkownikiem Eiichim Hirose. Ciekawym faktem jest kwestia danych z Azerbejdżanu, Hiszpanii czy Szwajcarii. Informacje napływające $\mathrm{z}$ tych miejsc miały oznaczenie bardzo ważnych i wysoko oceniono ich rzetelność. Kolejnymi potencjalnymi źródłami informacji stali się jeńcy oraz zdobyczne dokumenty. Przesłuchania oparte były na specyficznej konstrukcji rozmowy i selekcji pytań. Rozpoczynano od niezobowiązujących tematów i pytań, by następnie poruszać coraz bardziej szczegółowe kwestie dotyczące miejsca służby, dowódców, dyslokacji jednostek czy sygnałów rozpoznawczych. Informacje na ten sam temat, w celu weryfikacji, „wyciągane" były z wielu więźniów. Jednym ze znanych obozów jenieckich był Ofunie ${ }^{12}$ w prefekturze Kanagawa. Działał tam pułkownik Toshiro Imai, który prowadził dziennik. Z jego zapisków, przytoczonych przez Kotaniego, dowiedzieć się można, że „(...) przepytywani nie znali tematów rozmów. Pomiędzy niewinne pytania wplataliśmy zapytania o interesujące nas fakty tak by nie wyczuwali, że są poddawani przesłuchaniu. Używając tej metody, możliwe było wyeliminowanie straty czasu potrzebnego na przymusowe przesłuchanie, a jedocześnie minimalizowało to ryzyko uzyskania fałszywych informacji”"13. Z rozmów tych uzyskiwano informacje m.in. o dokładnych ruchach okrętów podwodnych, z określonymi godzinami opuszczania przystani czy liczbie dni postoju w porcie. Dzięki nim udawało się wyliczyć ogólną liczbę okrętów w danych sektorach morskich, jak i ocenić ich zasięg mobilizacji. Na zakończenie warto wspomnieć jeszcze o dokumentach otrzymywanych od Rzeszy. Większość z nich pochodziła od załóg okrętów lub pilotów. Jednym z ciekawszych stał się przechwycony plan ataku amfibiowego na Okinawę. Cały dokument liczył 200 stron i szczegółowo wprowadzał w zagadnienie. Według relacji Yuzuru Sanematsu instrukcje te okazały się bardzo przydatne w przygotowaniach do obrony Japonii i samej Okinawy ${ }^{14}$. Kolejnym interesującym dokumentem, który został przekazany przez stronę niemiecką, był egzemplarz zadań marynarki USA. Zawierał takie informacje, jak skład samej floty, fotografie jednostek czy ich wyposażenie. Dzięki temu japoński wywiad zapoznał się z zdjęciami lotniskowców klasy Essex i opracował

\footnotetext{
11 Y. Onodera, Barutokai no Hotori nite, Tokio 1992, s. 20-21.

12 T. Sasamoto, Tomb Inscription of Allied Prisoners of War, Tokio 2004, s. 192-194.

${ }^{13} \mathrm{~K}$. Kotani, Japanese Intelligence in WW II...

14 Y. Sanematsu, Nichibei Joho Senki, Tokio 1980, s. 214-215.
} 
nowe plany działań wobec jednostek tej kategorii. Wymiana samych informacji z Niemcami ${ }^{15}$, zgodnie z postanowieniami układu antykominternowskiego, a następnie postanowień o współpracy, nie przyniosła żadnych wymiernych efektów. Obieg informacyjny odbywał się między japońskim ambasadorem w Niemczech Hiroshim Oshimą a admirałem Wilhelmem Canarisem. Już w 1939 roku ten kanał okazał się praktycznie martwy i utrzymywano go tylko ze względu na podtrzymanie dobrych stosunków. Dodatkowo, wraz z podpisaniem paktu o nieagresji między Rzeszą a Związkiem Radzieckim, stracił rację bytu ${ }^{16}$. Wspomniany wcześniej Sanematsu w swojej książce o wywiadzie amerykańskim określił samą wymianę jako słabą. Ocenił, że Niemcy nie doceniali potencjału USA i bagatelizowali go nawet bardziej niż sami Japończycy ${ }^{17}$. Pierwszym problemem, jaki pojawił się i ciążył na wojskach japońskich, był podział między armią lądową a marynarką. Były to praktycznie dwie niezależne od siebie organizacje, z własnymi strukturami i przedstawicielstwem przy cesarzu. Jako ciekawostkę warto podać informację, że reprezentanci obu formacji mieli nieograniczony protokołem dostęp do samego cesarza, co w tamtym czasie było jednym z największych wyróżnień na cesarskim dworze. Między obiema organizacjami panowały gigantyczne antagonizmy, zaczynające się na najwyższych szczeblach, a kończące się na najniższych. O wymianie informacji praktycznie nie było mowy, w związku z czym działały dwie niezależne od siebie, a zarazem wrogie komórki: zarówno wywiadowcze, jak i kontrwywiadowcze. Idealnym przykładem tego jest posiadanie przez IJA danych dotyczących położenia sił Związku Radzieckiego na Dalekim Wschodzie oraz w samych Chinach. Aż do końca wojny informacje te nie zostały przekazane marynarce ani ministerstwu wojny.

Do początkowych operacji wywiadu IJA, o których warto wspomnieć, z pewnością można zaliczyć działania w okresie kampanii o Malaje ${ }^{18}$, rozpoczęte już w 1935 roku. Początkowo kwestią wywiadowczą zajmował się wojskowy attaché na Indonezję wraz z przedstawicielami armii Tajwan ${ }^{19}$. Jako że Tajwan należał od 1895 roku do Japonii, został on głęboko spenetrowany przez japoński wywiad. Głównym centrum działań stał się Bangkok. Założono wiele agencji,

\footnotetext{
15 R. Laomont-Brown, Kempeitait-japońska tajna policja, Warszawa 2004, s. 34-35.

16 N. Tajima, Nachizumu Kyokuto Senryaku, Tokio 1997, s. 45-48.

17 Y. Sanematsu, Nichibei Joho Senki..., s. 214.

18 J. Chapman, The Price of Admiralty, Sussex 1984, s. 526-530.

19 V. Madej, Japanese Armed Forces Order of Battle, 1937-1945, Allentown 1981, s. 87-95.
} 
m.in. F Kikan (znaną jako agencja F) czy Minami Kikan. Funkcjonowały one pod pretekstem promowania kultury japońskiej. Za wszystkie operacje na tym terenie odpowiedzialny był pułkownik Hiroshi Tamura, który działał pod przykrywką attaché w konsulacie. Społeczność tych terenów charakteryzowała się dość silną postawą antyjapońską, która utrudniała pracę wywiadowczą. Efektem tych starań było zaplanowanie lądowania sił w Hainan Dao ${ }^{20}$. Od roku 1940 zarówno ilość, jak i szybkość zdobywania informacji przez IJA zaczęły rosnąć, w związku z tym agencja zaczęła wysłać więcej agentów, by całkowicie zinfiltrować wyspę. Do samego końca wojny informacje te nie zostały przekazane marynarce ani ministerstwu. Dodatkowo podczas planowania ataków na europejskiego kolonie w 1941 roku powstała wspomniana już agencja F, której celem było podburzenie brytyjskich sił indyjskiego pochodzenia. Na jej czele stanął major Iwaichi Fujiwara. Z działaniami agencji wiązano dość duże nadzieje, gdyż ponad 70\% oddziałów stanowili właśnie tzw. niepewni żołnierze. Agencja nawiązała dość szybko współpracę z Indyjską Ligą Niepodległościąą i z liderem ruchu niepodległościowego Indii, Subhasem Czandra Bosem-22. Wskutek tej współpracy podczas całej kampanii skapitulowało wielu pojedynczych żołnierzy, a nawet całych oddziałów. Drugą ważną operacją w początkowej fazie II wojny światowej stały się działania na terenie Hongkongu. 12 października 1941 roku generał porucznik Jun Ushiroku, dowódca 23. armii ekspedycyjnej na Chiny, wydał rozkaz stworzenia planu zdobycia tego miasta. W samej metropolii działała już, jako organizacja rozwoju Azji, zakonspirowana agencja Koa, dowodzona przez podpułkownika Yoshimase Okade.

Plan działania agencji opierał się na dwóch kwestiach. Pierwsza zakładała aktywną pomoc armii japońskiej w trakcie operacji. Działania agentów miały uniemożliwić wojskom brytyjskim zniszczenie głównych dróg do Hongkongu, a w przypadku niemożności wykonania tego zadania skutecznie je opóźnić. Szkolono także przyszłych przewodników, mających oznaczyć łatwe drogi do miasta. Drugą kwestią stało się szpiegostwo oraz zakłócanie komunikacji. W tym wypadku plan działania opierał się na zniszczeniu elektrowni, punktów telefonicznych, źródeł wody oraz torów kolejowych. Realizacja tych planów wymagała

20 P.S. Dull, A Battle History of the Imperial Japanese Navy 1941-1945, Annapolis 1978, s. $36-37$.

21 P. Ward Fay, The Forgotten Army: India's Armed Struggle for Independence, 1942-1945, Ann Arbor 1995, s. 109-111.

22 J. Lebra, The Indian National Army and Japan, Singapore 1971, s. 21-23. 
nie tylko dość sporych funduszy, ale równie odpowiedniego zaplecza zaopatrzeniowego. Agencja pozyskała usługi lokalnej triady, dzięki czemu zakres zbieranych informacji został mocno rozszerzony. Ósmego grudnia 1941 roku wydano rozkaz rozpoczynający operacje; poza niewielkimi problemami wszystkie cele zostały osiągnięte: indyjskie baraki, elektrownia Kowloon, tory pociągowe oraz większość ujść wody zostało zdobytych i zniszczonych. Poza tym zamachy wykonywane na cywilach, szczególnie brytyjskiego pochodzenia, wprowadziły Hongkong w stan całkowitego chaosu ${ }^{23}$.

W działaniach wywiadowczych marynarki japońskiej, IJN, głównymi wrogami praktycznie we wszystkich planach były USA oraz Anglia. Japończycy, świadomi dysproporcji sił oraz praw Lanchester, wierzyli, że są w stanie zniszczyć siły Royal Navy. Myśl tę wyartykułował szef 8. sekcji 3. departamentu japońskiej marynarki, kapitan Kanyei Chudo: „Wierzymy, że brytyjska dalekowschodnia flota może zostać zniszczona bez problemu. W związku z wojną toczoną w Europie, Royal Navy nie jest w stanie wysłać odpowiednio silnych posiłków to tego regionu"24. Jeżeli zaś chodzi o walkę z oddziałami amerykańskimi, przeważała opinia o możliwej równej walce do jednego roku. Wywiad i dowództwo marynarki zakładały, że siły amerykańsko-brytyjskie są nierozerwalne, w związku z tym nie da się uniknąć wojny na dwóch frontach. Operacje zawsze były zatem przeprowadzone $\mathrm{z}$ perspektywą starcia $\mathrm{z}$ większymi siłami ${ }^{25}$. Całkowicie inne podejście miała armia lądowa, zakładająca, że pokonana Anglia lub Ameryka skapitulują i przedstawiciele władzy zapomną o sojusznikach. Niestety z punktu taktycznego założenia marynarki nie były błędne, a wręcz bardzo racjonalne. W każdym omawianym i testowanym scenariuszu konflikt z USA, trwający powyżej jednego roku, kończył się całkowitą klęską Japonii. W siłach imperialnej marynarki japońskiej nie znalazły się komórki potrafiące planować i przewidywać długofalowe operacje. Największą, a zatem jedyną ważną operacją z punktu widzenia tego artykułu jest atak na Pearl Harbor, opracowany przez szefa połączonych flot Isoroku Yamamoto. W styczniu 1941 roku Yamamoto wydał rozkaz kontradmirałowi Takijiro Onishiemu, dowódcy sztabu 11. powietrznej floty, zdobycia informacji i zaplanowania całej operacji. Pierwsze działania rozpoczęły

23 J.R. Stobie, A Reappraisal of U.S. Intelligence Prior to the Pacific War, Kansas 2007, s. 43.

${ }^{24}$ A.J. Mader, Old Friends, New Enemies: The Royal Navy and the Imperial Japanese Navy, vol. 2: The Pacific War, Oxford 1990, s. 340.

${ }^{25}$ C. Hosoya, Nihon no Eibeikan to Senkanki no Higashi-Ajia, Tokio 1982, s. 29-30. 
się na Hawajach. Jednym z głównych agentów został Takeo Yoshikawa z 3. sekcji 5. departamentu amerykańskiego wywiadu generalnego sztabu marynarki. Jego aktywność rozpoczęła się od obserwacji siedziby marynarki oraz bazy sił powietrznych Hickam i spisywania rozkładów lotów oraz rozłożenia patroli. By uniknąć wykrycia przez amerykańskie służby, Yoshikawa składał raporty na ręce japońskiego oficera Minato Nakajimy, który przebywał na Hawajach pod przykrywką przedstawiciela japońskiego MSZ. W tamtym czasie istniało zbyt duże ryzyko wykrycia raportów nadawanych za pomocą fal radiowych, w związku z tym liczba i częstotliwość składania raportów była opóźniona.

Kolejne działania przeprowadzone były przez dwóch szpiegów: Tatsute Maru oraz Taiyo Maru, którzy przepłynęli na kupieckim okręcie płynącym z Jokohamy do San Francisco. Szpiedzy obserwowali trasy okrętów zmierzających i wypływających z Pearl Harbor, określali także miejsca zakotwiczenia amerykańskiej floty. Ich działania informacyjne okazały się skuteczne i pomogły w zaplanowaniu samego ataku.

W początkowym okresie wojen napotykano liczne problemy i popełniano różnej wagi błędy. Pierwszym problemem okazały się wycieki danych, czego doświadczyły głównie siły marynarki. Takimi przykładami stały się uzyskane przez Amerykanów walizki z kodami, które zostały zastosowane w bitwie o Midway czy podczas próby zamordowania admirała Yamamoto w trakcie operacji „Vengeance”. Pierwsze walizki z kodami zostały zdobyte podczas zatopienia okrętu podwodnego I-124 w styczniu 1942 roku, druga para kodów w kwietniu 1944 roku.

Kolejnym problemem stał się brak prawdziwych sił kontrwywiadowczych w szeregach marynarki. W porównaniu z IJA, IJN nie widziała potrzeby rozbudowywania tej formacji. Dopiero w ostatniej fazie wojny zaczęto planować jej dalszy rozwój. Przez większość wojny nie złamano kodów i szyfrów IJA, w przeciwieństwie do tych stosowanych przez IJN. Kody IJN oparte były na ograniczonej liczbie numerów losowych, mogły zatem zostać złamane przy wykorzystaniu sprawdzonych metod deszyfracji. Poza tym zmiany szyfrów następowały rzadko, a komunikacja była częsta, w związku z czym siły amerykańskie do września 1942 roku miały rozszyfrowany w pełni kod JN-25 oraz jego drugą wersję, $\mathrm{JN}-25 \mathrm{~b}^{26}$. Był to jeden $\mathrm{z}$ głównych powodów porażki wojsk japońskich w bitwie o Midway. Mimo tej świadomości Japończycy główną odpowiedzialność zrzucili

${ }^{26}$ M. Smith, The Emperor's Codes: Bletchley Park and the breaking of Japan's secret ciphers, New York 2000, s. 169-181. 
na nie do końca dopracowane szczegóły techniczne całego starcia, np. problemy z kooperacją ze statkami zaopatrzeniowymi czy nieudolność w odnalezieniu pozycji wrogich sił na morzu. Kontradmirał Ryunosuke Kusaka przyznał w swoich zapiskach o przebiegu bitwy o Midway, że „Fakt, że planowane posunięcia połączonej floty z planami o Midway wyciekły do Amerykanów, były jedną z głównych powodów porażki tej operacji” ${ }^{27}$. Podobna sytuacja miała miejsce podczas operacji „Vengeance”, gdy zaplanowano zamach na admirała Yamamoto. Samolot admirała został zestrzelony, gdyż - jak wspomniano - amerykańskim siłom udało się przechwycić oraz złamać szyfr JN-25b, nazywany szyfrem wiadomości NTF131755, dzięki czemu Amerykanie poznali informacje dotyczące lotów bombowca transportującego admirała. Od tego momentu IJN brała pod uwagę możliwość złamania swojego szyfru ${ }^{28}$ przez Amerykanów. Niestety opieszałość japońskich śledczych, jak i brak skonkretyzowanych działań nie dały jednoznacznych odpowiedzi w sprawie złamania kodów. Warto w tym miejscu przytoczyć słowa pułkownika Sunao Sameshima, dowódcy sekcji wywiadu marynarki: „Incydent był bardzo ważny dla Imperialnej Japońskiej Marynarki. Stąd przeprowadzono natychmiastowe oraz szczegółowe śledztwo, uwzględniając możliwość, że jedna lub więcej naszych zakodowanych wiadomości mogła zostać rozszyfrowana. Niestety nie mogliśmy znaleźć nawet jednego potwierdzającego materiału o tym, że Amerykanie znali trasę inspekcji admirała Yamamoto przed samą podróżą. Kody były silne i niedawno, bo pierwszego kwietnia, uległy odnowieniu, założyliśmy więc, że nie było możliwości ich złamania. Następnego dnia, dziewiętnastego, w transmisji z San Francisco, Amerykanie oznajmili o zestrzeleniu przez ich siły na północnych wyspach Salomona japońskiej jednostki. Japońska strona skłaniała się bardziej ku temu, że był to przypadek. W konsekwencji nigdy nie przyszło nam do głowy, by odnowić lub zmienić dokumentacje kodów"29. Trudno wyobrazić sobie aż taką ignorancję, która stała się powodem zestrzelenia w roku następnym (1944 r.) dwóch łodzi latających. Na jednej z nich znajdował się naczelny dowódca połączonych flot, admirał floty Mineichi Koga. W drugiej zaś przebywał kontradmirał Shigeru Fukudome, szef sztabu połączonych flot; na pokładzie znajdowała się również wodoodporna teczka z dokumentami dotyczącymi kontrataku na amerykańskie wojsko oraz operacji Z oraz szyfry. Na nieszczęście

${ }^{27}$ K Kotani, Japanese Intelligence in WW II..., s. 22.

${ }^{28}$ H. Agawa, Shinban Yamamoto Isoroku, Tokio 1969, s. 377.

${ }^{29} \mathrm{~K}$ Kotani, Japanese Intelligence in WW II..., s. 23. 
dla Japończyków ocaleni z katastrofy zostali odnalezieni przez partyzantkę Cebu i wzięci w niewolę. Po sporządzeniu kopii planów Amerykanie postanowili je zwrócić Japończykom za pośrednictwem ludności Cebu. Ewentualne przejęcie dokumentów nigdy nie zostało uwzlędnione przez dowództwo IJN, które całą uwagę skupiło na postawie Fukudome, który, oddając się w niewolę, pogwałcił zasady instrukcji dla oficerów, zakładające samobójstwo w wypadku pojmania.

Warto przypomnieć o problemie braku wymiany informacji między obiema formacjami. $\mathrm{Z}$ tego powodu $\mathrm{w}$ drugiej połowie wojny sekcja wywiadu IJA została całkowicie „zapchana” wszelakiego rodzaju materiałami, które nie były weryfikowane i bardzo często wykluczały się, często też nie przedstawiały pełnego obrazu sytuacji. Na skutek tego doszło do paraliżu w przepływie informacji. Reakcją IJA stało się zwyczajne ignorowanie takich raportów i posługiwanie się wiedzą zdobytą na własną rękę.

Przykładem takiej ignorancji lub złej interpretacji może być kwiecień roku 1944, kiedy japoński wywiad odkrył, że atak amerykańskiej marynarki zostanie przeprowadzony na Mariany, ze szczególnym uwzględnieniem Saipanu, w okresie między majem a czerwcem. Informacja była dość szczegółowa, jednak biuro generalne armii całkowicie ją zbagatelizowało, zakładając, że atak zostanie przeprowadzony na Filipinach oraz Nowej Gwinei.

Szef połączonych flot, Tasuku Nakazwa, mówił: „Mariany prawdopodobnie jednego dnia staną się celem, ale na pewno nie teraz czy w czerwcu”. Kapitan Chikao Yamamoto, szef biura generalnego, wypowiadał się w podobnym tonie: „To nie jest tak, że nie braliśmy wysp Mariańskich pod uwagę, po prostu nie zakładaliśmy tego wydarzenia tak wcześnie ${ }^{30}$ ". Podobnym problemem dezinformacji stała się bitwa powietrzna o Tajwan i Okinawę, która rozegrała się w dniach 12-16 października w 1944 roku. Siły japońskie poniosły dość duże straty, jednak kwatera główna otrzymała raporty o zwycięstwie, w którym Amerykanie stracili 19 lotniskowców oraz cztery statki wojenne. Taka informacja szybko obiegła całą Japonię. Gdyby była prawdziwa, praktycznie cała flota USA musiałaby przestać istnieć. Źródłem takiej dezinformacji stali się niedoświadczeni członkowie załóg lotniczych, którzy nie zostali dokładnie przepytani. Nie potwierdzono tych „faktów" również w biurze wywiadowczym.

Tarcia między wywiadem a głównym sztabem IJA i wydziałem operacji nasiliły się w ostatnim okresie wojny. Sztab opracowywał plany obrony wysp

${ }^{30}$ Y. Sanematsu, Nichibei Joho Senki..., s. 236. 
japońskich na podstawie frontowych relacji oficerów i żołnierzy, obserwujących podniebne starcia bitwy o Tajwan i Okinawę, wywiad zaś zbierał informacje za pomocą nasłuchu oraz obserwacji strony amerykańskiej. Dzięki temu udało się oszacować siły amerykańskie, jakie miałyby dokonać planowanej inwazji. Jednak wyniki tych szacunków nie zostały zaakceptowane ze względu na możliwość osłabienia bojowego ducha żołnierzy, liczby zostały więc mocno zaniżone. Podobnie było z liczbami dotyczącymi ataków kamikaze. W wielu wypadkach dowództwo nie chciało zaakceptować faktów i wolało przyjmować oficjalne wersje milsze propagandzie, wskutek czego sześciokrotnie przekazano informację o zatopieniu okrętu Lexington czy czterokrotnie - Saratogi. Sam imperator zwrócił na to uwagę podczas jednego ze składanych mu raportów ${ }^{31}$.

Kiedy weźmiemy pod uwagę działalność agencji wywiadowczych, stanie się jasne, jak ogromną ilość informacji pracownicy musieli przerabiać i analizować. Brak unormowania, jak również usystematyzowania procedur działania i wewnętrzne antagonizmy sprawiły, że wraz z postępującymi kampaniami system wywiadu i kontrwywiadu zaczynał ulegać erozji, by w ostatnim okresie doznać praktycznie całkowitego paraliżu. Współcześnie, aby uniknąć tego typu problemów, należy przede wszystkim budować współpracę między odpowiednimi służbami, by agencje kontrwywiadowcze i wywiadowcze się uzupełniały, oraz eliminować ewentualne antagonizmy panujące między danymi formacjami. Kolejną refleksją jest nietworzenie zbyt dużej liczby jednostek mających takie same lub podobne kompetencje. Pozwoli to uniknąć sytuacji, w jakiej znalazło się Cesarstwo Japońskie. Następnym punktem jest kwestia umiejętnego kontrolowania poczynań jednostek wywiadowczych. Tu za przykład mogą posłużyć działania służb japońskich na terenach Mandżurii, gdzie osobiste korzyści majątkowe często kolidowały z zadaniami stawianymi przez dowództwo. Wówczas agenci tworzyli siatki mające bardziej charakter zorganizowanych grup przestępczych niż wywiadowczych. Wymienione działania pozwolą na ominięcie wielu problemów i aberracji. Jest to kilka refleksji, nad którymi warto się pochylić, zwłaszcza w obecnych czasach, kiedy informacja nabrała jeszcze większego znaczenia, a wojna przyswoiła dodatkowo wymiar niematerialny i coraz częściej rozpoczyna się w sferze działań związanych z obiegiem informacji.

31 Tamże, s. 229. 


\section{Bibliografia}

Agawa H., Shinban Yamamoto Isoroku, Tokio 1969.

Bennett J., Hobart W.A., Spitzer J.B., Intelligence and cryptanalytic activities of the Japanese during World War II, Walnut Creek 1986.

Chapman J., The Price of Admiralty, Sussex 1984.

Hinsley F.H., British Intelligence in the Second World War, London 1971.

Hosoya C., Nihon no Eibeikan to Senkanki no Higashi-Ajia, Tokio 1982.

Dull P.S., A Battle History of the Imperial Japanese Navy 1941-1945, Annapolis 1978.

Kotani K., Japanese Intelligence in World War II, Oxford 2009.

Kotani K., Japanese Intelligence in WWII: Successes and Failures, „NIDS Security Reports" 2009, No. 10.

Lamont-Brown R., Kempeitait - japońska tajna policja, Warszawa 2004.

Lebra J., The Indian National Army and Japan, Singapore 1971.

Lutton C., Pearl Harbor: Fifty Years of Controversy, „The Journal of Historical Review” 1991, vol. 11 (4).

Madej V., Japanese Armed Forces Order of Battle, 1937-1945, Allentown 1981.

Mader A.J., Old Friends, New Enemies: The Royal Navy and the Imperial Japanese Navy, vol. 2: The Pacific War, Oxford 1990.

Onodera Y., Barutokai no Hotori nite, Tokio 1986.

Sanematsu Y., Joho Sakusen ni Tsuite (Zenhso), Tokio 1972.

Sanematsu Y., Nichibei Joho Senki, Tokio 1980.

Sasamoto T., Tomb Inscription of Allied Prisoners of War, Tokio 2004.

Smith M., The Emperor's Codes: Bletchley Park and the breaking of Japan's secret ciphers, New York 2000.

Stobie J.R., A Reappraisal of U.S. Intelligence Prior to the Pacific War, Kansas 2007.

Tajima N., Nachizumu Kyokuto Senryaku, Tokio 1997.

Ward Fay P., The Forgotten Army: India's Armed Struggle for Independence, 1942-1945, Ann Arbor 1995.

Yoshimura A., Kaigun Otsu Jiken, Tokio 1982.

\section{Abstrakt}

Autor tekstu skupia się na trzech ważnych kwestiach dotyczących japońskiego wywiadu i jego działania w okresie II wojny światowej. Pierwszym poruszanym zagadnieniem jest kwestia zdobywania informacji oraz kodów, którymi posługiwali się Japończycy. Dochodzi tu do dwóch interesujących narracji. Pierwsza, amerykańska, głosi, że wszystkie 
kody imperialne zostały złamane i sprawnie użyte, i druga, japońska, mówiąca, że Japończycy byli w stanie łamać szyfry alianckie oraz sowiecki, lecz trudnością okazało się obrabianie materiału. Następnym zagadnieniem poruszanym przez autora są ważne z perspektywy Japonii operacje, które pozwoliły opanować Hongkong czy zaatakować Pearl Harbor. Ostatnim istotnym zagadnieniem poruszanym w tekście jest słynna nienawiść oraz otwarta wrogość między siłami lądowymi i marynarką, która widoczna była na wszystkich płaszczyznach, w tym również na polu wywiadowczym. Niechęć do dzielenia się zdobytymi materiałami, usuwanie niewygodnych agentów czy mnożenie problemów, które miały opóźnić rywala, były na porządku dziennym. Spowodowało to ogromny chaos podczas całej wojny, co w ostatecznym rozrachunku doprowadziło do upadku Kraju Kwitnącej Wiśni. Podsumowując, losy wywiadu japońskiego są dobrą lekcją dla obecnych sił na temat działania podczas początkowych faz konfliktu, unikania tworzenia wielu jednostek agenturalnych oraz wyeliminowania niezdrowej konkurencji.

\title{
The Japanese Intelligence Service and its Mistakes during the Pacific War. Which Mistakes Should Be Avoided
}

\begin{abstract}
The article presents three important questions concerning the Japanese intelligence service and its operations during the Second World War. The first question is how the service gained information and codes, which were used in the agency.

The first question includes two interesting threads. According to the Allies all the imperial codes had been broken and efficiently used; and according to the Japanese the Allied and Soviet codes had been broken, but later they turned out to be difficult to process.

The second question concerns the operations - important from the Japanese point of view - which resulted in capturing Hong Kong and in attacking Pearl Harbor.

The last question is the notorious hatred and open hostility between the ground and naval forces. Those emotions were present on all the planes, the intelligence service including. Valuable information was hardly shared, inconvenient agents were sometimes eliminated, problems were multiplied to delay the rival, etc. It caused total chaos during the war and finally it brought about the collapse of the land of the rising sun.

The changing fortunes of the Japanese intelligence are a good lesson to teach present intelligence agencies how to behave in the initial phases of a conflict, how to avoid creating too many intelligence units and how to eliminate unfair competition.
\end{abstract}

